\title{
A FIZIKAI INAKTIVITÁS NÉPEGÉSZSÉGÜGYI JELENTŐSÉGE
}

\section{PUBLIC HEALTH IMPORTANCE OF PHYSICAL INACTIVITY}

\author{
Poór Gyula \\ az MTA levelezó tagja, fóigazgató, egyetemi tanár, \\ Országos Reumatológiai és Fizioterápiás Intézet, Budapest, Semmelweis Egyetem, Budapest \\ poor.gyula@orfi.hu
}

\begin{abstract}
ÖSSZEFOGLALÁS
A dolgozat a fizikai inaktivitás nemzetközi és hazai nagyságrendjének ismertetése után a kérdés fogalmi meghatározásaival és az aktivitás mérésével foglalkozik. Ismerteti azokat a legfontosabb civilizációs népbetegségeket, melyek létrejötte összefügg a fizikai inaktivitással, és elemzi a degeneratív mozgásszervi kórképek (oszteoporotikus törések, artrózis) kialakulását. Végül a kellő fizikai aktivitás eléréséhez vezető teendőket foglalja össze, melyek a közeljövőben az egészségügyi kormányzat által elindított Nemzeti Mozgásszervi Programban kerülhetnek megvalósításra.
\end{abstract}

\section{ABSTRACT}

The paper deals with the worldwide and home magnitude of physical inactivity as well as definitions and measurements regarding activity itself. The author outlines the most important civilizatory public health diseases that are related to physical inactivity, and analyses the background of degenerative muskuloskeletal disorders (osteoporotic fractures, osteoarthritis). Finally the tasks leading to optimal physical activity are discussed that will be realized in the close future in the National Musculoskeletal Programme initiated by the healthcare authorities.

Kulcsszavak: fizikai inaktivitás, nemzetközi és hazai jelentőség, fogalmi meghatározások és mérések, civilizációs népbetegségekkel való kapcsolat, egyéni és társadalmi teendők, Nemzeti Mozgásszervi Program

Keywords: physical inactivity, worldwide and domestic trends, definitions and measurements, association with public health diseases, individual and governmental tasks, National Musculoskeletal Programme 


\section{A KÉRDÉS NAGYSÁGRENDJE}

A számítógép-, mobiltelefon- és televízió-képernyőkre fókuszáló mai civilizált élet sajnálatos módon nem igényli a mozgást, ami számtalan káros következménnyel jár. Egy átfogó WHO-publikáció szerint (Lee et al., 2012) a krónikus, nem fertőző betegségek fizikai inaktivitással járó világméretü asszociációja hat-tíz százalék közé tehető, és a fizikai inaktivitásnak tulajdonítható halálozások becsült száma világszerte évente több mint 5,3 millió fö. A fizikai inaktivitás eliminálásával potenciálisan nyerhető átlagos életnyereség $0,68(0,41-0,95)$ év lehetne.

A sporttevékenység által végzett fizikai aktivitás mutatói a teljes magyar lakosság körében végzett kutatás szerint is drámaiak (Eurobarometer, 2010). A populáció 53\%-a soha, semmilyen sporttevékenységet nem végez, 24\%-a csak havonta 1-3 alkalommal vagy ritkábban, tehát elmondható, hogy a hazai populáció 77\%-a fizikailag inaktív. Az inaktivitással összefüggő betegségek hazai összköltségterhe, a lakosságnak tulajdonítható kockázat alapján számolva 283,5 milliárd forint (Ács et al., 2011), és a jelenlegi inaktivitás csupán 10\%-os, tehát 67\%-ra való csökkentése évi 9,1 milliárd forint megtakarítást eredményezne. A hazai férfiak $6,4 \%$-a, a nők 9,9\%-a csak nagy nehézséggel vagy egyáltalán nem képes 500 m-t gyalog, sík terepen segédeszköz nélkül megtenni. A WHO által vezetett nemzetközi tanulmány részeként végzett HBSC-vizsgálatban (Health Behaviour in School-Aged Children) a megkérdezett diákok harmada kevés, több mint egynegyedük nagyon kevés fizikai aktivitást végez, és csak közel egyötödükre jellemző, hogy eleget mozognak (NEFI, 2016).

\section{FOGALMI MEGHATÁROZÁSOK, A FIZIKAI AKTIVITÁS MÉRÉSE}

A fizikai aktivitás a harántcsíkolt izmok által történő bármely testi mozgás, mely energiafelhasználással jár (foglalkozás, háztartás, testedzés, egyéb). A testedzés, testgyakorlás (exercise) olyan fizikai aktivitás, mely tudatosan tervezett, strukturált, repetitív, és célja a fizikai fittség javítása vagy fenntartása. Az aerob jellegủ dinamikus edzés (kardioreszpiratorikus fitnesz - séta, kocogás, ugrálás, tánc stb.) dominanciája mellett anaerob izomfejlesztő - ellenállásos gyakorlatok (izomfitnesz - fekvőtámasz, guggolás, lépcsőzés, súlyzózás stb.), és idős korban egyensúlyjavító/esésmegelőző gyakorlatok végzése szükséges. A versenyszerü testedzést sportnak nevezzük. A fizikai fittség (fitnesz) a fizikai jóllét állapota, melyet számos komponens (kardioreszpiratorikus teljesítmény, állóképesség, izomerö, izomkoordináció, ízületi flexibilitás, optimális testsúly) együttesen eredményez. 
A fizikai aktivitás általánosan elfogadott mértékegysége a kcal, illetve kJ helyett ma elsősorban a metabolikus ekvivalencia (MET). Ez utóbbi a fizikai aktivitás hatására a test által elfogyasztott energia mennyiségét fejezi ki, és megadja, hogy az hányszorosa a nyugalomban mért oxigénszükségletnek, ami 1 MET (3,5 $\mathrm{ml} \mathrm{O} \mathrm{O}_{2} / \mathrm{tskg} /$ perc). A leggyakrabban használt MET-perc/hét energia felhasználást a terhelés alatti metabolikus ráta és a testedzés percben kifejezett hetenkénti idejének szorzata adja.

A fizikai aktivitás fokozatait MET-ben adjuk meg, mely szerint gyenge intenzitású ( $<3$ MET), közepes intenzitású (MET 3-6) és erős intenzitású ( $>6$ MET) aktivitást különböztetünk meg (Ainsworth et al., 2011), a 3 MET alatti gyenge aktivitás gyakorlatilag inaktivitásnak felel meg (1. táblázat).

1. táblázat. A fizikai aktivitás fokozatai metabolikus ekvivalenciában (MET) kifejezve

\begin{tabular}{|l|c|}
\hline \multicolumn{1}{|c|}{ Fizikai aktivitás } & MET \\
\hline \multicolumn{1}{|c|}{ Gyenge intenzitású } & $<3$ \\
\hline Alvás & 0,9 \\
\hline Ülés nyugalomban (tv-nézés) & 1 \\
\hline Íróasztali munka & 1,5 \\
\hline Nagyon lassú séta (2,7 km/óra) & 2,3 \\
\hline Lassú séta (4 km/óra) & 2,9 \\
\hline \multicolumn{1}{|c|}{ Közepes intenzitású } & $3-6$ \\
\hline Szobabiciklizés (50 W) & 3 \\
\hline Gyorsabb séta (4,8 km/óra) & 3,3 \\
\hline Gimnasztika kp intenzitással & 3,5 \\
\hline Gyors séta (5,5 km/óra) & 3,6 \\
\hline Biciklizés (16 km/óra) & 4 \\
\hline Szobabiciklizés (100 W) & 5,5 \\
\hline Szexuális aktivitás & 5,8 \\
\hline & Erős intenzitású \\
\hline Kocogás & $>6$ \\
\hline Gimnasztika erős intenzitásal (pl. ugrálás, helybenfutás) & 7 \\
\hline Ugrókötelezés & 8 \\
\hline & 10 \\
\hline
\end{tabular}




\section{A FIZIKAI INAKTIVITÁS/AKTIVITÁS CIVILIZÁCIÓS NÉPBETEGSÉGEKKEL VALÓ KAPCSOLATA}

A fizikai inaktivitás civilizációs népbetegségekkel való kapcsolata a bizonyítékokon alapuló orvoslás szigorú kritériumai szerint is igen szoros (1. ábra). A fizikai inaktivitás a szív- és érrendszeri betegségek (kardiovaszkuláris kórképek, stroke, hipertónia), a metabolikus betegségek (obezitás, diabétesz mellitusz2, köszvény, lipidanyagcsere-zavarok, metabolikus szindróma), a tumorok (kolorektális és mammakarcinóma), valamint a mentális anomáliák és betegségek (motiváció hiánya, kognitív funkciózavarok, szorongás, depresszió, Parkinson-kór, Alzheimer-kór, drogfüggőség) kialakulásának fontos kockázati tényezője, míg a fizikai aktivitás ugyanezen állapotokban protektív hatású (Haskell et al., 2007; Paillard et al., 2015). A fizikai fittség az alapját képezi a szellemi és lelki egyensúlynak is.

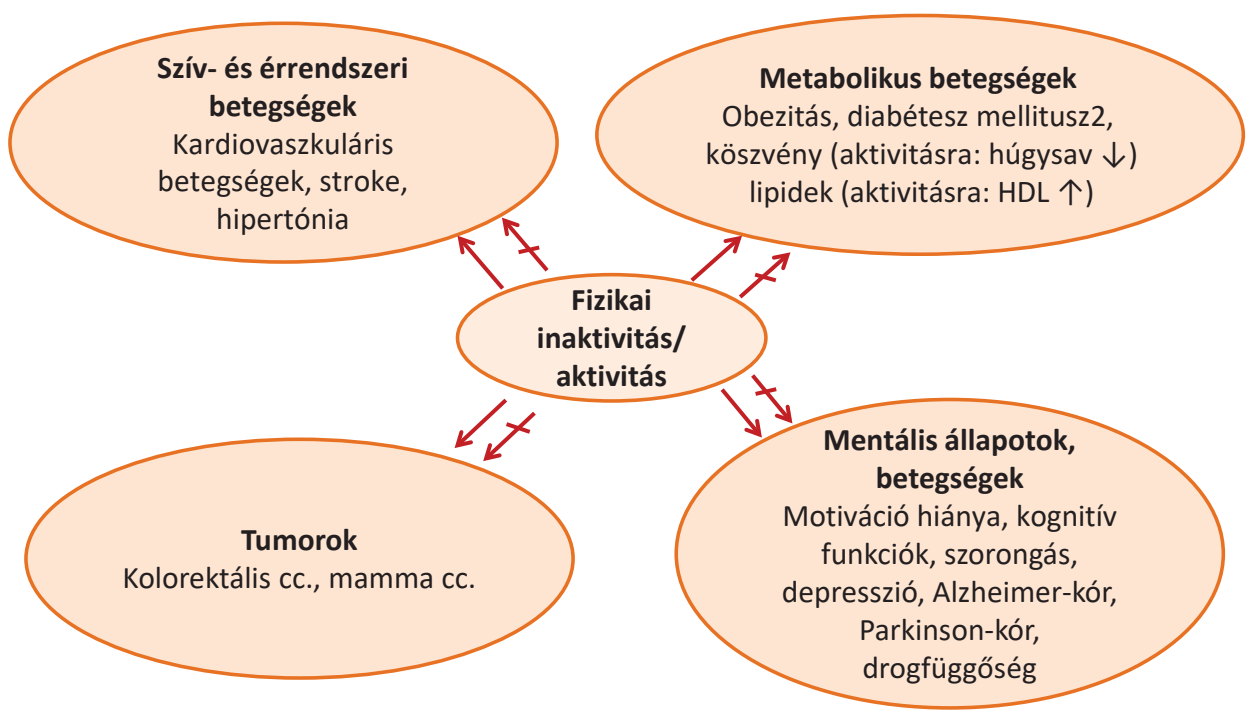

1. ábra. A fizikai inaktivitás/aktivitás belgyógyászati és idegrendszeri kórképekkel való kapcsolata

Saját szerkesztés

A fizikai inaktivitásnak a mozgásszervi kórképek kialakulásában játszott szerepe még markánsabb. A gyermek- és serdülőkorúak tartási és statikai rendellenességei (szkoliózis, kifózis és a következményes későbbi szpondilózis, pedes plani, valgusz-varusz deformitások stb.), az akut és krónikus derékfájás, a végtagízületi artrózis, valamint az oszteoporózis és a következményes frakturák hátterében az inaktivitás komoly rizikótényező, míg ugyanitt a nem extrém fizikai aktivitás 
védő szerepe is egyértelmü. A fiatalkori csúcscsonttömeg létrejötte, és a kellő csontdenzitás megörzése szempontjából például meghatározó a tartós oszteoblaszt-inger, ami vertikális irányú impakt terheléssel, vagyis a saroknak a földhöz való ütődésével érhető el (2. ábra). Egy friss publikáció szerint a fizikai aktivitásnak komoly hatása van az immunrendszerre is, mely a természetes immunitás elemeinek erősítéséből, és a T-helper 1 adaptív citokinválasz csökkentéséből áll, aminek az általános védekezőképesség és az autoimmun betegségek elleni védettség szempontjából is jelentősége lehet (Sharif et al., 2018).

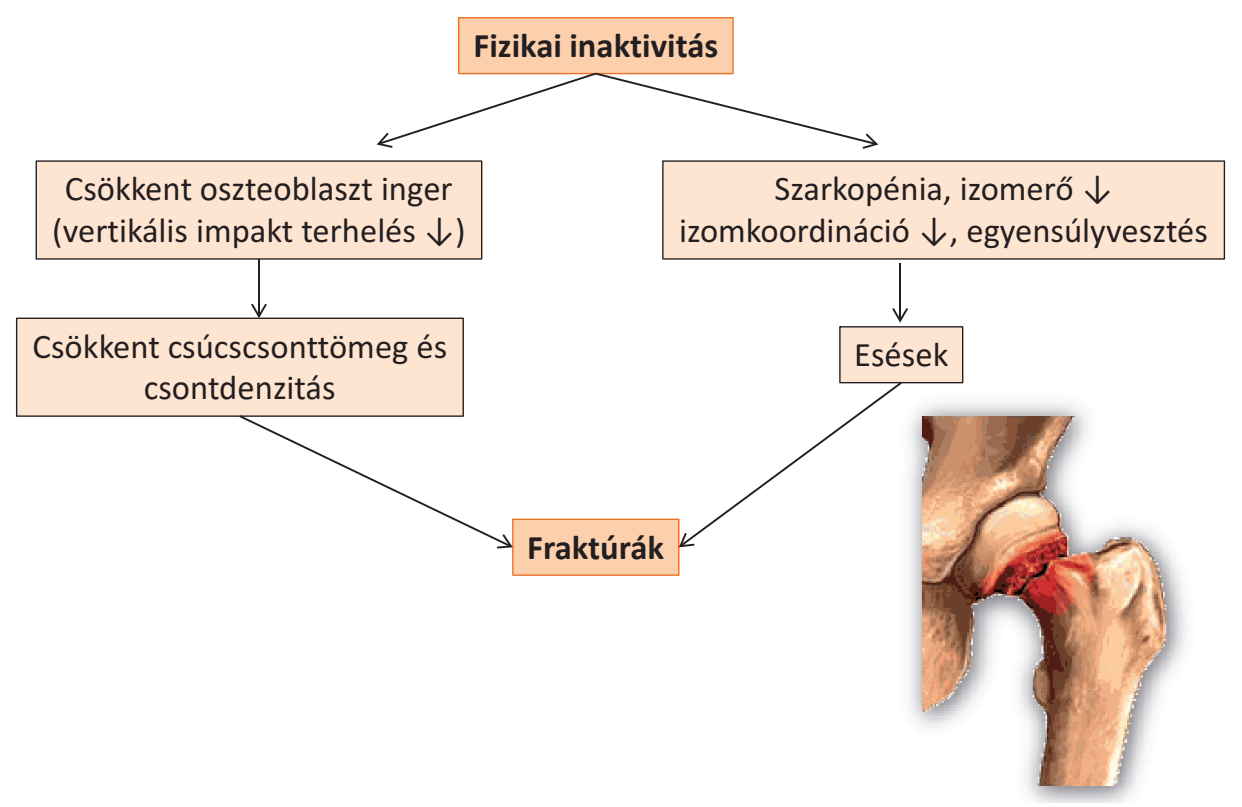

2. ábra. A fizikai inaktivitás és az oszteoporotikus törések kapcsolata

Saját szerkesztés

Az artrózis kialakulásában (3. ábra) a nagyobb testsúly és az elhízás hatása meghatározó (Gates et al., 2017). Minden egyes testsúlykilogramm a fokozott ízületi terhelés révén $10 \%$-kal növeli vagy csökkenti a térdartrózis kockázatát, amit a szarkopénia miatti izomerö-csökkenés (például quadriceps izomzat), a gyengült propriocepció miatti ízületi instabilitás és a következményes mikrosérülések csak tovább növelnek. Friss OECD-adatok alapján elhízás vonatkozásában Magyarország Európában listavezető lett, és a világ összes országa tekintetében csak az Egyesült Államok, Mexikó és Új-Zéland előzi meg (OECD, 2017). A 2014es Európai Lakossági Egészségfelmérés (Európai Lakossági Egészségfelmérés, 2014) alapján a magyar lakosság 54\%-a túlsúlyos (testtömegindex, TTI: 25-30), 


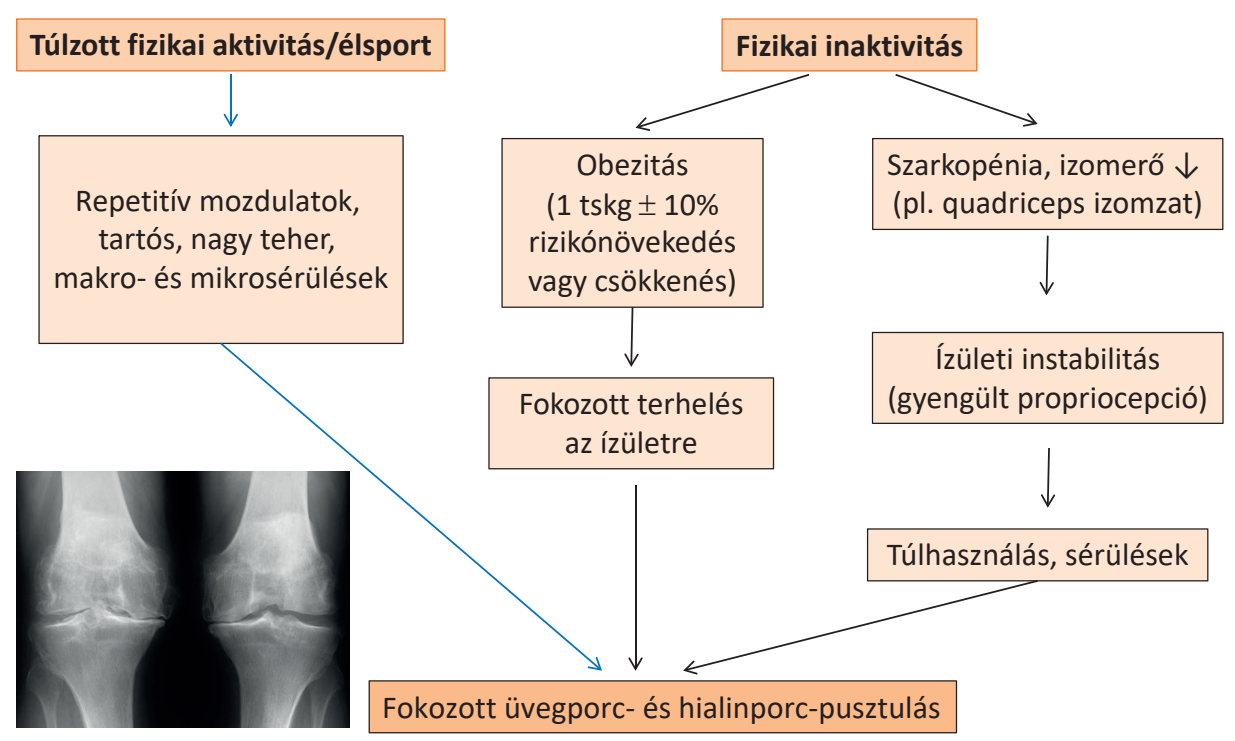

3. ábra. A fizikai inaktivitás és a túlzott aktivitás szerepe az artrózis kialakulásában

Saját szerkesztés

vagy elhízott (TTI: 30 felett); míg a nők 49\%-ának, addig a férfiak 62\%-ának volt magas testtömegindexe, ez az aggasztó tény az életkor növekedésével egyre kifejezettebbé válik. Ehhez a mozgáshiány mellett elsősorban az egészségtelen táplálkozás járul hozzá, a föleg állati eredetü zsírok és a szénhidrátok túlzó fogyasztásával, illetve a zsírlerakódást segítő magas fruktózbevitellel, ami a legtöbb üdítöital kukoricakeményítő sziruppal történő ízesítéséből származik (Buzás, 2016). Ugyanakkor azt is látnunk kell, hogy a túlzott fizikai aktivitás és az élsport is - a repetitív mozdulatok, a tartós nagy terhelések vagy az elszenvedett makro- és mikrosérülések révén - fokozott üvegporc- és hialinporc-pusztuláshoz, vagyis artrózishoz vezethet.

\section{TEENDŐK EGYÉNI ÉS TÁRSADALMI SZINTEN}

A fizikai aktivitás intenzitására és rendszerességére a WHO a különböző életszakaszok szerint ajánlásokat tett közzé (WHO, 2018). Ennek értelmében felnőttkorban (18-65 év) az optimális terhelés: napi 150 perc közepes vagy 75 perc erős intenzitású aerob aktivitást jelent, minimum 10 perces időtartamokkal, kiegészítve hetente két-háromszor izomfejlesztő gyakorlatokkal. A még biztosan hatásos minimális terhelés heti 150 perc közepes (például MET: 3,3-nak megfelelő gyorsabb séta) vagy heti 75 perc erős (például MET: 6,6-nak megfelelő kocogás) intenzitású 
edzés, ami összességében mintegy 500 MET-perc/hét energiafelhasználást jelent. Ennél kevesebb aktivitás biztosan nem hatásos. Idősebb korban ( $>65$ év) a változatlan felnőttkori ajánlás egyensúlyjavító és prevenciós gyakorlatokkal egészül ki, legalább heti háromszor. Gyermek- és fiatalkorban (5-17 év) legalább napi 60 perc közepes-erős intenzitású aerob fizikai aktivitás szükséges, kiegészítve izomerö- és csontdenzitás-növelő gyakorlatokkal heti háromszor. Az ajánlásoknak megfelelö testmozgás mellett is szükséges a hosszan tartó ülés megszakítása, mivel az külön kockázatot hordoz.

A fizikai aktivitást csak orvosi vizsgálatot (például EKG) követően lehet megkezdeni, és annak lehetőleg gyermekkortól kezdve, egész életen át, napi/heti rendszerességgel kell folynia. A mozgásprogramot mindig egyénre szabottan, a kortól, fizikai állapottól és egyéb betegségektől függően kell kialakítani. A terhelés fokozatos legyen, mérőeszközök (például óra, lépésszámláló, pulzusmérö stb.) által kontrollált, a bemelegítést (például stretching, gimnasztika) követően a tréning kellő terhelésig (kipirulás, verejtékezés, a beszédképesség határáig fokozódó szapora légzés, optimális pulzusszám emelkedés: 200 mínusz életkor) történjen. Megjegyzendő, hogy az optimális testsúly megőrzése a kellő fizikai aktivitás mellett a napi racionális kalóriabeviteltől is függ, amelynek az általában szükséges 2000 kcal-t nem szabad meghaladnia.

A fizikai inaktivitás leküzdésében az egyének mellett a társadalomnak is nagyon komoly szerepe van. Egészségügyi felvilágosító programok indításával el kell érni a lakosság egészségtudatos életvitelének erősítését, és ezen belül az optimális egészségfenntartó fizikai aktivitás iránti igényét. Divatba kell hozni a mozgást, és a különböző mozgásformák vonatkozásában tömegmozgalmakat kell létrehozni. A mindennapos iskolai testnevelés feltételeinek és szakmai kontrolljának (Somhegyi, 2014) javításán túl a napi mozgásprogramokat óvodai és felsőoktatási szinten is indokolt bevezetni, és a munkahelyi egészségmegörzés fejlesztése is szükséges. A tömegsport számára hozzáférések és facilitások biztosítása elsőrendủ fontosságú. Mindezen erőfeszítéseket részletesen összefoglalja az Emberi Erőforrások Minisztériuma felkérésére a jelen dolgozat szerzője által írt és szerkesztett Nemzeti Mozgásszervi Program, mely az összes korosztály, valamint az egészségesek és fogyatékosok vonatkozásában intervenciós programok és törvénymódosítási javaslatok sorát tartalmazza (Poór, 2018). A legfőbb cél, hogy a primer és szekunder prevenció révén a program elősegítse egy egészséges, fizikailag terhelhető, rendszeres mozgásigényü generáció felnövekedését. Reméljük, hogy a program és a többi négy nemzeti egészségprogram kormány által történő elfogadása és anyagi támogatása mielőbb megtörténik, ami a jelenlegi hazai egészségügyi helyzeten érdemben tud majd változtatni. 


\section{EPILÓGUS}

A régi rómaiak a test és lélek összefüggésével kapcsolatos meggyőződését Iuvenalis (Kr. u. 47-127) foglalta össze a Szatírákban, ahol, az utókor által helytelenül, csak félig idézett szentenciát hagyott ránk: „Orandum est, ut sit mens sana in corpore sano”, vagyis „Imádkozni kell azért, hogy ép testben ép lélek legyen”. Azért írhatta ezt a költő, mert a latinoknál a test még ép volt, mivel nem gyengült meg a civilizáció ártalmai következtében. Közel kétezer év elteltével már nemcsak a lelkünk, hanem a testünk egészségét is veszélybe sodortuk, ezért Iuvenalis mondását a következőképpen lehetne adaptálni a ma emberének: Orandum et faciendum est, ut sit corpus sanum. Imádkozni és tenni kell azért, hogy ép testünk legyen.

\section{IRODALOM}

Ács P. - Hécz R. - Paár D. et al. (2011): A fittség (m)értéke: A fizikai inaktivitás nemzetgazdasági terhei Magyarországon. Közgazdasági Szemle, 58, 689-708. http://old.econ.unideb.hu/iktv/ docs/szakirodalom/A_fittseg_merteke.pdf

Ainsworth, B. - Haskell, W. L. - Hermann, S. D. et al. (2011): Compendium of Physical Activities. Medicine \& Science in Sports \& Exercises, 43, 1575-1581. DOI: 10.1249/MSS.0b013e31821ece12, https://journals.lww.com/acsm-msse/fulltext/2011/08000/2011_Compendium_of_Physical_Activities_A_Second.25.aspx

Buzás Gy. M. (2016): A fruktóz és a fruktózintolerancia. Orvosi Hetilap, 157, 1708-1706. http:// real.mtak.hu/46488/1/650.2016.30567.pdf

Eurobarometer (2010): Sport and Physical Activity. http://ec.europa.eu/public_opinion/archives/ ebs/ebs_334-fact_ha_en.pdf_

Európai Lakossági Egészségfelmérés (2014). http://www.ksh.hu/elef

Gates, L. - Leyland, K. M. - Sheard, S. et al. (2017): Physical Activity and Osteoarthritis: A Consensus Study to Harmonise Self-reporting Methods of Physical Activity Across International Cohorts. Rheumatology International, 37, 469-478. DOI: 10.1007/s00296-017-3672-y, https:// link.springer.com/article/10.1007\%2Fs00296-017-3672-y

Haskell, W. L. - Lee, I. M. - Russel, R. P. et al. (2007): Physical Activity and Public Health: Updated Recommendation for Adults from the American College of Sports Medicine and the American Heart Association. Circulation, 116, 1-13. https://scholarcommons.sc.edu/cgi/viewcontent. cgi? article $=1117 \&$ context $=$ sph_physical_activity_public_health_facpub

Lee, I. M. - Shiroma, E. J. - Lobelo, F. (2012): Effect of Physical Inactivity on Major Non-communicable Diseases Worldwide: An Analysis of Burden of Disease and Life Expectancy. The Lancet, 380, 219-229. doi: 10.1016/S0140-6736(12)61031-9, https://www.ncbi.nlm.nih.gov/pmc/ articles/PMC3645500/

NEFI (2016): Az Iskoláskorú gyermekek egészségmagatartása elnevezésü, az Egészségügyi Világszervezettel együttmüködésben megvalósuló nemzetközi kutatás (HBSC) 2014. évi felméréséröl készült nemzeti jelentés. (szerk. Németh Á. - Költő A.) [Budapest]: NEFI, http://www. egeszseg.hu/szakmai_oldalak/assets/cikkek/16-05/egeszseg-es-egeszsgegmagatartas-iskolaskorban-2014.pdf

OECD (2017): Obesity Update. www.oecd.org/health/obesity-update.htm 
Paillard, T. - Yves, R. - de Souto Barreto, P. (2015): Protective Effects of Physical Exercise in Alzheimer's Disease and Parkinson's Disease: A Narrative Review. Journal of Clinical Neurology, 11, 2012-2019. DOI: 10.3988/jcn.2015.11.3.212, https:/www.ncbi.nlm.nih.gov/pmc/articles/ PMC4507374/

Poór Gy. (2018): Nemzeti Mozgásszervi Program. Az Emberi Erőforrások Minisztériuma felkérésére irt szakmai anyag

Sharif, K. - Watad, A. - Bragazzi, N. L. et al. (2018): Physical Activity and Autoimmune Diseases: Get Moving and Manage the Disease. Autoimmune Review, 17, 53-72. DOI: 10.1016/j. autrev.2017.11.010, https://www.researchgate.net/publication/320846785_Physical_activity_ and_autoimmune_diseases_Get_moving_and_manage_the_disease

Somhegyi A. (2014): A mindennapos testnevelés egészségfejlesztési kritériumai: megvalósításuk jelen helyzete. Népegészségügy, 92, 4-10. http://www.fjit.hu/docs/mt_egfejl_krit_nepegeszsegugy_2014_1_szam.pdf

WHO (2018): Physical Activity. http://www.who.int/news-room/fact-sheets/detail/physical-activity 